\title{
THE ALTERATION OF YOUNG BOXERS' ATHLETIC AND SPECIAL PHYSICAL FITNESS DURING THE FIRST YEAR OF THEIR PHYSICAL TRAINING
}

\author{
Algirdas Čepulėnas, Vitalijus Subačius, Vidas Bružas, Pranas Mockus \\ Lithuanian Academy of Physical Education, Kaunas, Lithuania
}

\begin{abstract}
Algirdas Čepulėnas. Professor, Dr. Habil. of Social Sciences (Education), Head of the Department of Sports Technologies, Lithuanian Academy of Physical Education. Research interests - modeling the management of the preparation of athlete training system.
\end{abstract}

\begin{abstract}
The goal of this study was to analyze the alteration of young boxers' athletic and special physical fitness during the annual cycle of their initial training.

Research methods: literature review, experiment, testing, comparative analysis, and mathematical statistics. The sample consisted of 14 persons, who were training boxing for one year. The average age of the boxers was $14.9 \pm 0.6$ years.

The duration of the experiment was 10 months (from September till June). The young boxers were training $1-1.5$ hours 5 times per week according to the program which was made for them. The training program of one alternative was applied in the experiment. The initial training program contained $24.6 \%$ of athletic training, $27.6 \%$ of special physical training, 28.5\% of technical training, and 19.3\% of tactical training. The testing of the boxers was performed three times: the first testing was in October, the second one - in February, and the third one - in June.
\end{abstract}

The following training means were used for the young boxers' athletic training program: physical exercises on the special equipment, exercises with partner, exercises with weights (dumbbells), short distance running, point-to-point running, various jumps, throwing of the stuffed ball, various games.

The main means for the young boxers'special training were imitation exercises, exercises with a rope and lawn tennis balls, exercises at the boxing bags, straight and side thrusts to the boxing bag, defense exercises, thrust imitation using the dumbbells and the stuffed balls.

During the annual cycle of the initial training there was a minor alteration in the indexes of the young boxers'body composition: their height, body weight and Ketle index increased $(p<0.05)$, while the amount of the fat $(\%)$ within the body and the body weight index changed very little $(p>0.05)$.

The strength of the sportsmen's right hand palm was always bigger than the strength of the left hand palm.

The boxers' athletic and special physical fitness improved $(p<0.05)$ during one year of their initial training. The boxers' speed, explosive strength, anaerobic glicolitic endurance, hand strength endurance and flexibility indexes increased significantly $(p<0.05)$. The strength of the single side thrusts with the front hand to the boxing bag increased from $106.3 \pm 7.5 \mathrm{~kg}$ to $127.6 \pm 8.15 \mathrm{~kg}(p<0,05)$. The strength of the single thrusts with the straight hand increased from $135.2 \pm 7.43 \mathrm{~kg}$ to $158.5 \pm 6.74 \mathrm{~kg}(p<0.05)$. The amount of the thrusts of the examined boxers during the period of $8 \mathrm{sec}$ increased $(p<0.05)$ in each testing period and at the end of the experiment, the average amount of the boxers' thrusts in $8 \mathrm{~s}$ was $43.5 \pm 2.9$.

The training program, determined for one alternative experiment significantly improved the preparation of young boxers and did not harm their health. During the annual preparation cycle the athletic and special physical fitness of the boxers improved. The implementation of this experimental program made a positive influence on the alteration of the body composition indices of the young boxers.

Keywords: athletic training, special physical training, boxing bag, energy input, total energy, total strength.

\section{INTRODUCTION}

$\mathrm{T}$ he initial stage of the young boxer's training is a very important part of the whole physical training through the years. At the beginning of their sports activity young men choose boxing mainly for the physical reasons, they wish to become physically strong (Buonamano et al., 1995; Malinauskas, 1998, 2003). There is no single opinion regarding the right age to start training boxing (Полиевский и др., 2002; Маркианов, Ананьев, 2004; Морозов, 2004). The surveys show (Маркианов, Ананьев, 2004) that $60 \%$ of the coaches recommend to start trai- 
ning boxing at the age of $10-11$ years, $13 \%$ of the coaches recommend the age of $11-12$ years, however some trainers claim that practicing specialized boxing should be started at the age of 13-14 years. V. Klicko (Кличко, 1999) divides the long-term training of young boxers into 3 stages: 1) the primary stage of basic training at the age of $14-15$ years; 2 ) the specialized stage of the training at the age of $16-17$ years; and 3 ) the stage of the realization of maximum capacities at the age of $18-20$ years.

There is evidence in research literature (Martin et al., 1993) that young boxers' training should begin at the age of $12.7 \pm 3.3$ years.

During the first stage of physical training it is very important to determine the match between young sportsmen's genetics, physical, functional abilities and the chosen type of sports, to adjust the measures and methods of athletic and special physical training properly and constantly control of the alteration of the sportsmen's physical fitness (Popadoupulos et al., 1997; Платонов, 2004). The features of young boxers' biomotor abilities are strongly influenced not only by the amount of physical load, but also by the strength and changeability of their individual nervous processes (Ревенко и др., 2005).

The loads of the general and special physical training, which do not comply with the requirements of the future specialization, can suppress the development of the young sportsmen's physical abilities and restrict them from achieving good results in the future (Волков, 2002; Пынтиков и др., 2005).

In order to conduct the initial young boxer's training well and to forecast the dynamics of their sports qualification, it is necessary to examine the level of their initial physical fitness and the dinamics of its alteration under the influence of the training loads.

The goal of the study was to examine the alteration of the athletic and special physical preparation of the beginner boxers during the annual cycle of the initial preparation.

\section{The tasks of this research:}

1. To determine the alteration of the young boxers' body composition during the annual cycle of the initial training.

2. To determine the alteration of the young boxers' athletic fitness during the annual cycle of the initial training.

3. To analyze and to evaluate the indexes of the young boxers' special physical fitness.

\section{MATERIALS AND METHODS}

Research methods used in the study were literature review, experiment, testing, comparative analysis, mathematical statistics (arithmetic mean $\overline{\mathrm{x}}$, standard deviation $\pm \mathrm{SD}$, arithmetic mean tolerance $\pm \mathrm{SE}$, the value of the mean differences $t$, according to the Stjudent criterion, the reliability of the mean differences (p).

Fourteen persons, who have been training boxing for one year, formed a research group. The average age of the boxers was $14.9 \pm 0.6$ years.

The duration of this experiment was 10 months (from September till June). The training program of one alternative was applied during the experiment. The young boxers had $1-1.5$ hour training 5 times per week according to the program, which was made for them (Figure 1, Table 1).

The testing of the boxers was performed three times: the first testing took place in October, the second one - in February, and the third one - in June.

The research program consisted of the following parts:

1. Determining of the body composition indexes (Skernevičius et al., 2004). The following indexes were determined: the height, the weight of the body and the body weight index (BMI), Ketle index, the strength of the hand palms, and the amount of the fat in the total body weight in percent. The weight of the body and the fat layer were registered using mobile TANITA BODY ANALYZER TВГ-551 weighting equipment.

2. The testing of athletic fitness: dash running

\begin{tabular}{|c|c|c|c|c|c|c|c|c|c|c|c|c|}
\hline \multirow{8}{*}{$\begin{array}{l}\text { Table } 1 \text {. The content } \\
\text { of young boxers' trai- } \\
\text { ning (experimental } \\
\text { program) }\end{array}$} & \multirow{2}{*}{ Structural parts of training } & \multicolumn{10}{|c|}{ Months } & \multirow[t]{2}{*}{ In total, $\mathrm{h}$} \\
\hline & & IX & $\mathrm{X}$ & $\mathrm{XI}$ & XII & I & II & III & IV & V & VI & \\
\hline & Athletic training, $\mathrm{h}$ & 7 & 7 & 6 & 6 & 5 & 5 & 5 & 5 & 5 & 5 & 56 \\
\hline & Special physical training, $\mathrm{h}$ & 7 & 7 & 7 & 6 & 6 & 6 & 6 & 6 & 6 & 6 & 63 \\
\hline & Tactical training, $\mathrm{h}$ & 1 & 2 & 4 & 4 & 5 & 6 & 6 & 6 & 5 & 5 & 44 \\
\hline & Technical training, $\mathrm{h}$ & 8 & 6 & 6 & 6 & 6 & 7 & 7 & 6 & 8 & 5 & 65 \\
\hline & Control exercises, $\mathrm{h}$ & & 5 & & & 2 & 3 & & & & 5 & 15 \\
\hline & Totally, h & 23 & 27 & 23 & 22 & 24 & 27 & 24 & 23 & 24 & 26 & 243 \\
\hline
\end{tabular}




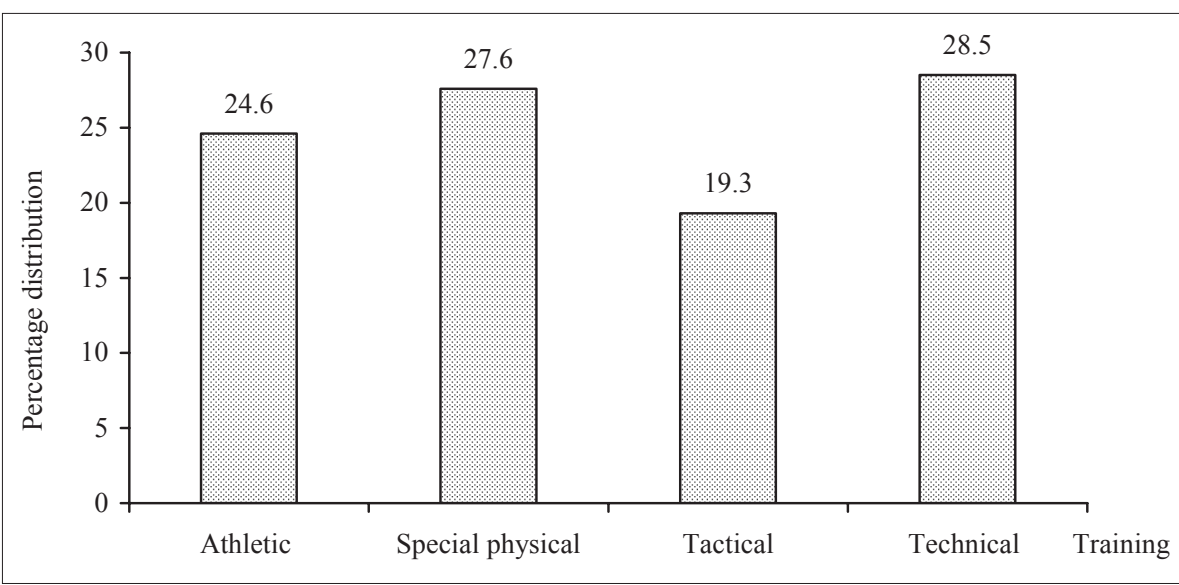

Figure 1. The distribution of young boxers' structural parts of training during the annual training cycle

(30 m), $500 \mathrm{~m}$ running, standing long jump, standing high jump on the contact platform, push-ups on the parallel bars, sit and reach and the test of hand movement speed (tapping test) were performed according to the "Eurofit" testing methods (Eurofitas. Fizinio pajegumo testai ir metodika, 2002).

3. The testing of special physical fitness: determination of the strength of the single thrust to the boxing bag with front or main hand, $8 \mathrm{sec}$ lunging to the boxing bag and registration of the thrusts' amount and strength ( $\mathrm{kg}$ ), as well as consumed energy according to V. Klicko (Кличко, 1999). A special boxing bag with computer equipment was used for this purpose. Special devices, mounted in the bag, calculated the amount and the strength of the thrusts and the energy input in joules $(\mathrm{J})$; registration of the boxer's simple and complex reaction to the light irritants (Skernevičius et al., 2004).

The following training means were used for the young boxers' athletic training program: physical exercises with special equipment, exercises with a partner, exercises with weights (dumbbells), short distance running, point-to-point running, various jumps, throwing the stuffed ball, and various games.
The main means for the young boxers' special training were imitation exercises, exercises with a rope and lawn tennis balls, exercises at the boxing bags, straight and side thrusts to the boxing bag, defense exercises, thrusts imitation using the dumbbells and the stuffed balls.

\section{RESULTS}

During the annual cycle of the initial training there was a minor alteration in the indexes of the young boxers' body composition (Table $2)$ : their height, body weight and Ketle index increased $(p<0.05)$, while the amount of the fat (\%) within the body and the body weight index changed very slightly $(\mathrm{p}>0.05)$. The strength of the left hand palm increased from $26.3 \pm 2.5$ to $30.0 \pm 3.0 \mathrm{~kg}$, and right palm increased from $28.0 \pm 2.6$ to $31.7 \pm 3.1 \mathrm{~kg}(\mathrm{p}<0.05)$. The strength of the sportsmen's right hand palm was always greater than the strength of the left hand palm.

The indexes of the young boxers' athletic training increased during the experimental period (Table 3). Boxers' complex quickness, sharp strength, anaerobic glicolitic endurance, hand strength endurance and flexibility indexes increased $(\mathrm{p}<0.05)$. With each testing stage the frequency of the hand

\begin{tabular}{|c|c|c|c|c|c|c|c|c|c|}
\hline \multirow{2}{*}{\multicolumn{2}{|c|}{ Testing }} & \multirow{2}{*}{$\begin{array}{l}\text { Body } \\
\text { weight, cm }\end{array}$} & \multirow{2}{*}{$\begin{array}{l}\text { Body } \\
\text { height, kg }\end{array}$} & \multirow[t]{2}{*}{ BMI, $\mathrm{kg} / \mathrm{m} 2$} & \multirow{2}{*}{$\begin{array}{l}\text { Ketle index, } \\
\mathrm{g} / \mathrm{cm}\end{array}$} & \multirow{2}{*}{$\begin{array}{l}\text { The amount of } \\
\text { fat in weight, \% }\end{array}$} & \multicolumn{2}{|c|}{$\begin{array}{l}\text { The strength of the } \\
\text { hand palms, } \mathrm{kg}\end{array}$} & \multirow{9}{*}{$\begin{array}{l}\text { Table } 2 \text {. The alte- } \\
\text { ration of young } \\
\text { box e r s b od y } \\
\text { composition in- } \\
\text { dexes ( } \pm \text { SE) du- } \\
\text { ring the first year } \\
\text { of training }\end{array}$} \\
\hline & & & & & & & Left & Right & \\
\hline \multicolumn{2}{|l|}{ I } & $166.6 \pm 2.0$ & $55.5 \pm 3.2$ & $19.8 \pm 0.7$ & $331.2 \pm 15.4$ & $11.4 \pm 0.7$ & $26.3 \pm 2.5$ & $28.0 \pm 2.6$ & \\
\hline \multicolumn{2}{|l|}{ II } & $169.1 \pm 2.2$ & $57.3 \pm 3.1$ & $19.8 \pm 0.6$ & $336.6 \pm 14.4$ & $11.8 \pm 0.8$ & $28.4 \pm 2.8$ & $29.4 \pm 3.2$ & \\
\hline \multicolumn{2}{|l|}{ III } & $170.6 \pm 2.3$ & $59.0 \pm 3.0$ & $20.1 \pm 0.6$ & $343.7 \pm 13.7$ & $11.2 \pm 0.8$ & $30.0 \pm 3.0$ & $31.7 \pm 3.1$ & \\
\hline \multicolumn{9}{|c|}{ The reliability of the averages' differences } & \\
\hline $\mathrm{I}-\mathrm{II}$ & $\begin{array}{l}\mathrm{t} \\
\mathrm{p}\end{array}$ & $\begin{array}{l}7.49 \\
<0.05\end{array}$ & $\begin{array}{l}6.96 \\
<0.05\end{array}$ & $\begin{array}{l}0.15 \\
>0.05\end{array}$ & $\begin{array}{l}2.60 \\
<0.05 \\
\end{array}$ & $\begin{array}{l}0.73 \\
>0.05\end{array}$ & $\begin{array}{l}2.52 \\
<0.05\end{array}$ & $\begin{array}{l}1.69 \\
>0.05\end{array}$ & \\
\hline II-III & $\begin{array}{l}\mathrm{t} \\
\mathrm{p}\end{array}$ & $\begin{array}{l}4.58 \\
<0.05\end{array}$ & $\begin{array}{l}4.63 \\
<0.05 \\
\end{array}$ & $\begin{array}{l}1.86 \\
>0.05 \\
\end{array}$ & $\begin{array}{l}3.34 \\
<0.05\end{array}$ & $\begin{array}{l}1.04 \\
>0.05\end{array}$ & $\begin{array}{l}3.10 \\
<0.05\end{array}$ & $\begin{array}{l}3.35 \\
<0.05\end{array}$ & \\
\hline I-III & $\begin{array}{l}\mathrm{t} \\
\mathrm{p}\end{array}$ & $\begin{array}{l}7.88 \\
<0.05 \\
\end{array}$ & $\begin{array}{l}6.17 \\
<0.05 \\
\end{array}$ & $\begin{array}{l}1.00 \\
>0.05 \\
\end{array}$ & $\begin{array}{l}3.26 \\
<0.05 \\
\end{array}$ & $\begin{array}{l}0.98 \\
>0.05\end{array}$ & $\begin{array}{l}3.73 \\
<0.05\end{array}$ & $\begin{array}{l}3.86 \\
<0.05\end{array}$ & \\
\hline
\end{tabular}


Table 3. The alteration of young boxers' athletic fitness during the annual training cycle $(\overline{\mathbf{X}} \pm \mathrm{SE})$

\begin{tabular}{|c|c|c|c|c|c|c|c|c|c|}
\hline \multirow{2}{*}{\multicolumn{2}{|c|}{ Testing }} & \multirow{2}{*}{$\begin{array}{l}\text { Dash running } \\
(30 \mathrm{~m}), \mathrm{s}\end{array}$} & \multirow{2}{*}{$\begin{array}{l}500 \mathrm{~m} \\
\text { running, s }\end{array}$} & \multirow{2}{*}{$\begin{array}{l}\text { Standing long } \\
\text { jump, cm }\end{array}$} & \multirow{2}{*}{$\begin{array}{l}\text { Standing } \\
\text { high jump, } \\
\mathrm{cm}\end{array}$} & \multirow{2}{*}{$\begin{array}{l}\text { Push-ups on } \\
\text { the parallel } \\
\text { bars, time }\end{array}$} & \multirow{2}{*}{$\begin{array}{l}\text { Sit and } \\
\text { reach, cm }\end{array}$} & \multicolumn{2}{|c|}{$\begin{array}{l}\text { The test of hand move- } \\
\text { ment - speed-tapping test, } \mathrm{s}\end{array}$} \\
\hline & & & & & & & & Left & Right \\
\hline I & & $5.38 \pm 0.11$ & $106.3 \pm 2.7$ & $184.3 \pm 6.1$ & $29.5 \pm 1.5$ & $9.2 \pm 1.2$ & $25.4 \pm 2.2$ & $12.5 \pm 0.5$ & $12.3 \pm 0.4$ \\
\hline II & & $5.19 \pm 0.12$ & $102.3 \pm 3.6$ & $190.1 \pm 6.5$ & $30.8 \pm 1.5$ & $10.6 \pm 1.3$ & $27.7 \pm 1.8$ & $12.1 \pm 0.5$ & $11.8 \pm 0.5$ \\
\hline III & & $5.06 \pm 0.10$ & $101.9 \pm 2.4$ & $193.0 \pm 6.3$ & $32.4 \pm 1.4$ & $12.1 \pm 1.2$ & $30.3 \pm 1.8$ & $11.8 \pm 0.5$ & $10.9 \pm 0.3$ \\
\hline \multicolumn{10}{|c|}{ The reliability of the averages' differences } \\
\hline $\mathrm{I}-\mathrm{II}$ & $\mathrm{t}$ & $\begin{array}{l}2.84 \\
<0.05\end{array}$ & $\begin{array}{l}1.88 \\
>0.05\end{array}$ & $\begin{array}{l}3.09 \\
<0.05\end{array}$ & $\begin{array}{l}1.35 \\
>0.05\end{array}$ & $\begin{array}{l}3.39 \\
<0.05\end{array}$ & $\begin{array}{l}2.86 \\
<0.05\end{array}$ & $\begin{array}{l}3.31 \\
<0.05\end{array}$ & $\begin{array}{l}2.48 \\
<0.05\end{array}$ \\
\hline II-III & $\mathrm{t}$ & $\begin{array}{l}4.18 \\
<0.05\end{array}$ & $\begin{array}{l}0.15 \\
>0.05\end{array}$ & $\begin{array}{l}3.90 \\
<0.05\end{array}$ & $\begin{array}{l}1.36 \\
>0.05\end{array}$ & $\begin{array}{l}4.36 \\
<0.05\end{array}$ & $\begin{array}{l}3.92 \\
<0.05\end{array}$ & $\begin{array}{l}2.23 \\
<0.05 \\
\end{array}$ & $\begin{array}{l}4.75 \\
<0.05 \\
\end{array}$ \\
\hline I-III & $\mathrm{t}$ & $\begin{array}{l}5.49 \\
<0.05\end{array}$ & $\begin{array}{l}4.03 \\
<0.05\end{array}$ & $\begin{array}{l}4.45 \\
<0.05\end{array}$ & $\begin{array}{l}2.10 \\
>0.05\end{array}$ & $\begin{array}{l}6.28 \\
<0.05\end{array}$ & $\begin{array}{l}5.66 \\
<0.05\end{array}$ & $\begin{array}{l}3.33 \\
<0.05\end{array}$ & $\begin{array}{l}5.45 \\
<0.05\end{array}$ \\
\hline
\end{tabular}

Table 4. The alteration of young boxers' psychomotoric reaction ( $\bar{X} \pm S E$ ) during the annual cycle of the initial training

\begin{tabular}{|c|c|c|c|}
\hline \multirow{2}{*}{\multicolumn{2}{|c|}{ Testing }} & \multicolumn{2}{|c|}{ Psychomotoric reaction, $\mathrm{ms}$} \\
\hline & & Simple & Complex \\
\hline I & & $204.1 \pm 5.3$ & $258.3 \pm 6.0$ \\
\hline II & & $197.5 \pm 5.4$ & $245.5 \pm 5.3$ \\
\hline III & & $196.0 \pm 3.9$ & $239.9 \pm 5.7$ \\
\hline \multicolumn{4}{|c|}{ The reliability of the mean differences } \\
\hline $\mathrm{I}-\mathrm{II}$ & $\begin{array}{l}\mathrm{t} \\
\mathrm{p}\end{array}$ & $\begin{array}{l}1.04 \\
>0.05\end{array}$ & $\begin{array}{l}1.06 \\
>0.05\end{array}$ \\
\hline II-III & $\begin{array}{l}\mathrm{t} \\
\mathrm{p}\end{array}$ & $\begin{array}{l}0.30 \\
>0.05\end{array}$ & $\begin{array}{l}0.98 \\
>0.05\end{array}$ \\
\hline $\mathrm{I}-\mathrm{III}$ & $\begin{array}{l}\mathrm{t} \\
\mathrm{p}\end{array}$ & $\begin{array}{l}1.36 \\
>0.05\end{array}$ & $\begin{array}{l}2.22 \\
<0.05\end{array}$ \\
\hline
\end{tabular}

Figure 2. The alteration of the strength of the single thrust of young boxers during the annual training cycle $(\overline{\mathbf{X}} \pm \mathrm{SE})$

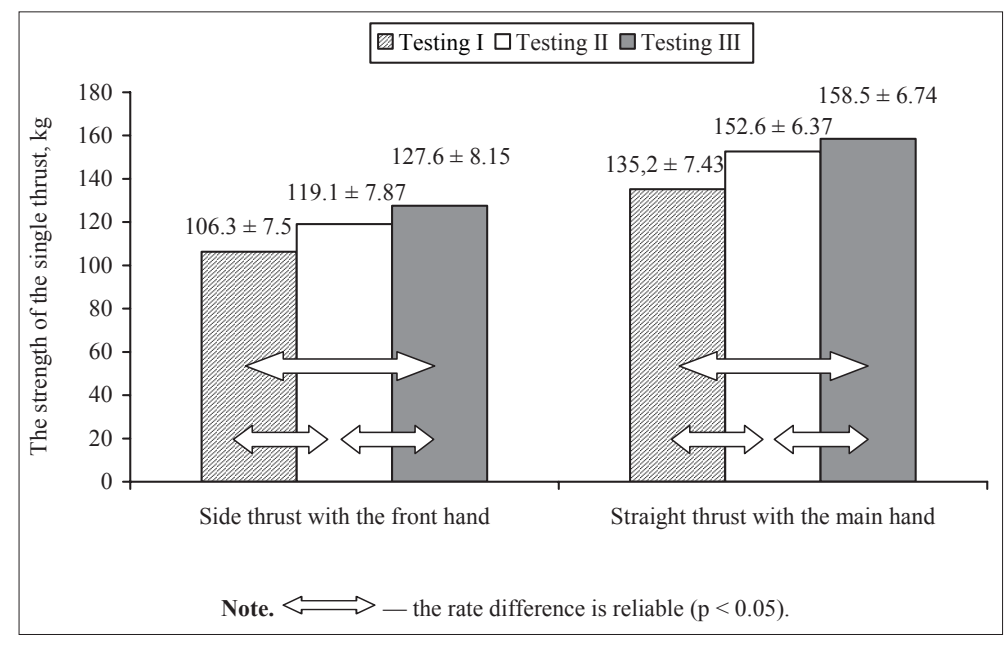

increased from $135.2 \pm 7.43$ to $158.5 \pm 6.74 \mathrm{~kg}$ $(\mathrm{p}<0.05)$. The number of thrusts to the boxing bag during $8 \mathrm{~s}$ is a very important index of the boxers' special physical fitness. The number of thrusts during $8 \mathrm{~s}$ of the research participants increased $(p<0.05)$ during each testing period and at the end of the experiment, the average number of the boxers' thrusts during $8 \mathrm{~s}$ was $43.5 \pm 2.9$ (Figure 3). During the experimental period the total strength of the boxers thrusts to the boxing bag (the strength of all the thrusts during $8 \mathrm{~s}$ ) increased from $1892.4 \pm 256.3$ to $2702.5 \pm 251.2 \mathrm{~kg}$ (Figure 4). The energy input (j) for the performance of $8 \mathrm{~s}$ lunging to the boxing bag with maximum effort increased as well (Figure 5). from $106.3 \pm 7.5$ to $127.6 \pm 8.15 \mathrm{~kg}(\mathrm{p}<0.05)$. The strength of the single thrusts with the straight hand 

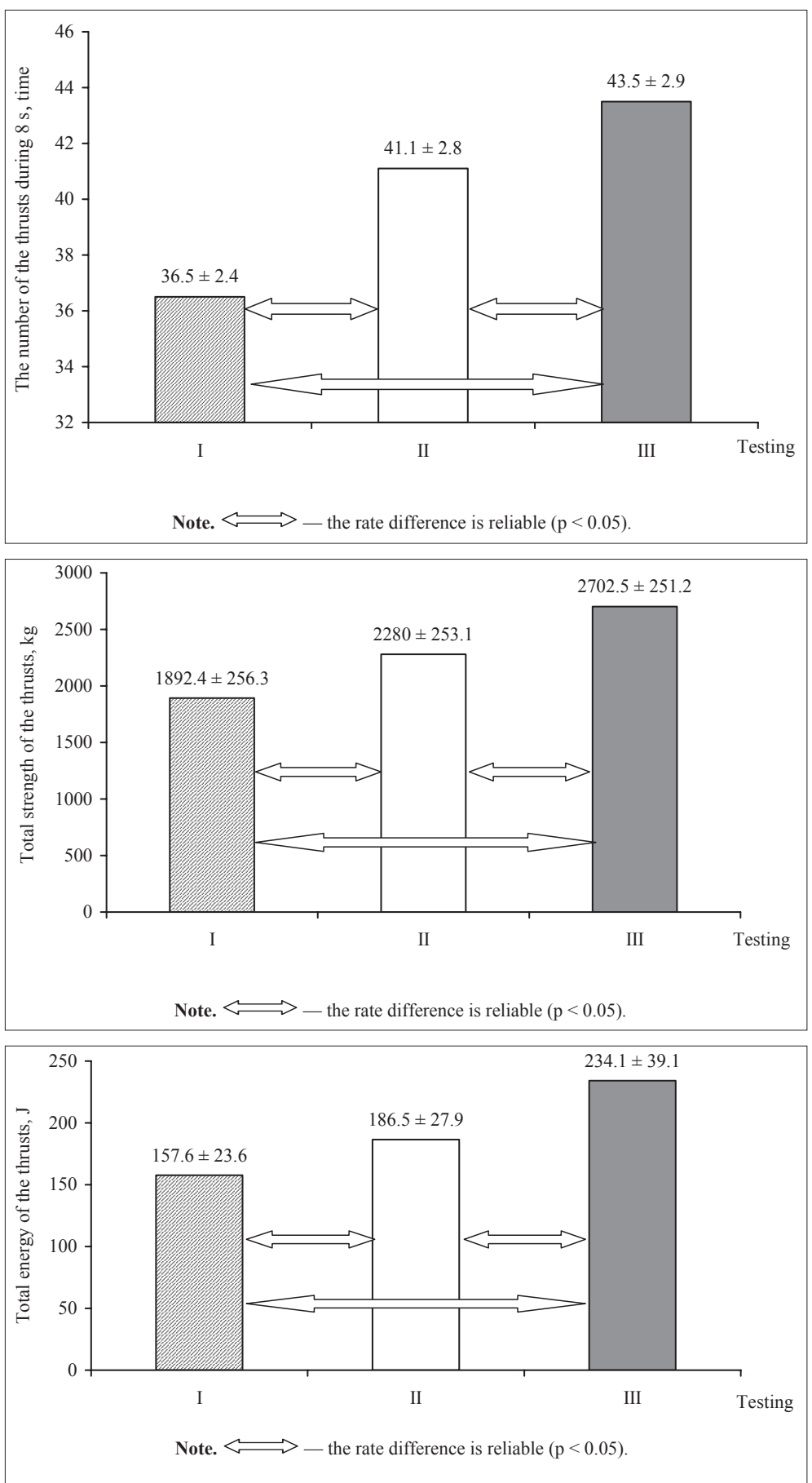

Figure 3. The alteration of the number of the thrusts during the young boxers' 8 sec lunging to the boxing bag during the first year of training $( \pm \mathrm{SE})$
Figure 4. The alteration of the total strength of the thrusts during young boxers' $8 \mathrm{sec}$ lunging to the boxing bag $(\overline{\mathbf{X}} \pm \mathrm{SE})$
Figure 5. The alteration of the total energy of the thrusts during young boxers' 8 sec lunging to the boxing bag in the first year of training $(\bar{x} \pm \mathrm{SE})$

\section{DISCUSSION}

The implementation of the young boxers' training program (Table 1, Figure 1) positively influenced the alteration of their body composition indexes (Table 2). The athletic and special physical fitness of the examined boxers improved significantly during the one-year cycle of the initial training. While exercising the young boxers' psychomotorics, it is very important to consider the individual features of their psychical, emotional and nervous systems, whereas the alteration of their biomotor abilities is closely related to the features of the nervous system and emotional status (Пынтиков и др., 2005; Ревенко и др., 2005). There is evidence in the special literature on boxing (Полиевский и др., 2002; Морозов, 2004), that in the initial period of training it is necessary to perform general training exercises with a partner, special boxing exercises in pairs, to perform a lot of quickness and coordination exercises, applying the "training in a circle" methods.

It was found (Морозов, 2004), that the results of $11-13$ years old boxers in $30 \mathrm{~m}$ running correlated ( $\mathrm{r}$ from -0.515 to -0.673 ) with their technical qualification. 
The implementation of the experimental training program made positive influence on the alteration of the young boxers' psychomotoric abilities: the results of $30 \mathrm{~m}$ running, the frequency of the hand movement, and the number of the thrusts to the boxing bag during $8 \mathrm{sec}$ improved $(\mathrm{p}<0.05)$. The duration of the simple psychomotoric reaction decreased from $204.1 \pm 5.3$ to $196.0 \pm 3.9 \mathrm{~ms}(\mathrm{p}>0.05)$. The duration of the complex psychomotoric reaction of the perspective young boxers is $216 \mathrm{~ms}$ (Полиевский и др., 2002), while during the third testing our boxers' rate was $239.9 \pm 5.7 \mathrm{~ms}$. The research by Bouchard and Malina (1994) shows, that at the young age physical fitness and biomotor abilities improve at certain periods of life: the strength of muscle retraction increases at the age of $9-15$ years, strength abilities - at the age of 13-14 years, and quickness - at the age of 9-15 years.

The alteration of young sportsmen's physical fitness is strongly influenced by their genetic abilities, the proportion between the distribution of different preparation types, the amount and intensity of training in various training stages (Волков, 2002; Wilmore, Costill, 2004).

It was noticed (Пынтиков и др., 2005), that young boxers with strong nervous system, perform more thrusts, and those, whose nervous processes changeability is greater, demonstrate better abilities in quickness. In accordance with the model characteristics (Кличко, 1999) of the initial basic training for 14-15 year old boxers, the single thrusts strength with front and main hand of the research participants corresponded to the average level, while the total strength of thrusts in $8 \mathrm{~s}$ was lower than the average level of evaluation. The total strength of thrusts to the boxing bag during $8 \mathrm{~s}$ lunging shows the strength and frequency of the thrusts. It was determined by other researchers (Полиевский и др., 2002; Морозов, 2004) that boxers' training programs for $11-13$ year boys, where integral training of speed-strength abilities dominates together with the formation and the development of lunging actions technique, strongly influence the improvement of the boxers' body composition and physical fitness. The program, related to the content of the experimental young boxers' training, was approved in this study.

\section{CONCLUSIONS}

The sports training program, determined for the one alternative experiment, significantly improved the preparation of the young boxers and did not harm their health.

The preparation program for the young boxers (the structure of which contained $24.6 \%$ of athletic training, $27.6 \%$ of special physical training, $28.5 \%$ of technical training, and $19.3 \%$ of tactical training of all the time for training) was effective. During the annual preparation cycle the athletic and special physical fitness of the boxers improved. The implementation of this experimental program made a positive influence on the alteration of the body composition rates of young boxers.

\section{REFERENCES}

Bouchard, C., Malina, R. M. (1997). Genetics of Fitness and Physical Performance. Human Kinetics.

Buonamano, R., Cei, A., Mussino, A. (1995). Participation motivation in Italian youth sport. The Sport Psychologist, 3, 265-281.

Eurofitas. Fizinio pajègumo testai ir metodika. (2002). Sud. V. Volbekienè, S. Kavaliauskas. Vilnius: Lietuvos Sporto informacijos centras.

Malinauskas, R. (2003). Didelio meistriškumo dvikovos sporto šakų sportininkų ir jų rezervo motyvacijos ypatumai. Sporto mokslas, 1 (31), 19-23.

Malinauskas, R. (1998). Vaikinu, kurie renkasi boksa, motyvacijos ypatumai. Sporto mokslas, 3 (12), 20-22.

Martin, D., Carl, K., Lehnerta, K. (1993). Handbuch Trainingslehre. 2 unweränd. Aufl. Schornddorf: Hofmann Verlag.

Papadoupolos, Ch., Salonikidis, K., Achmidtbleicker, D. (1997). Diagnose and Auswertung der Auswertung der motorischen Fähigkeiten Kraft und Schnelligkeit bei Kindern im Alter Zwicken 10 bis 15 Jahren. Leistungssport, $6(27), 26-30$.
Skernevičius, J., Raslanas, A., Dadelienè, R. (2004). Sporto mokslo tyrimu metodologija. Vilnius: LSIC.

Wilmore, J. H., Costill, D. L. (2004). Physiology of Sport and Exercise. Human Kinetics. P. 526-536.

Волков, Л. В. (2002). Теория и методика детского и юношеского спорта. Киев: Олимпийская литература.

Кличко, В. (1999). Бокс: теория и методика спортивного отбора. Киев: Нора-принт.

Маркианов, О. А., Ананьев, А. А. (2004). Отношение тренеров к системе соревнований в юношеском боксе. Физическая культура: воспитание, образование, тренировка, 1, 28-29.

Морозов, О. С. (2004). Формирование технических приемов у юных боксеров. Физическая культура: воспитание, образование, тренировка, 2, 37-38.

Платонов, В. Н. (2004). Система подготовки спортсменов в олимпийском спорте. Общая теория и ее практические приложения. Киев: Олимпийская литература.

Полиевский, С. А., Подливаев, Б. А., Худадов, Н. А., Киселев, В. А., Мартынов, М. В. (2002). Возрастная граница занятий боксом. Физическая культура: воспитание, образование, тренировка, 4, 28-32. 
Пынтиков, А. А., Сальников, В. А., Яцин, Б. В., Ревенко, Е. М., Кузьмин, В. (2005). Индивидуальные особенности темпов прироста скоростных и скоростно-силовых проявлений у боксеров, различающихся уровнем подготовленности. Физическая культура и спорт в системе образования. Здоровьесберегающче технологии и формирование здоровья: материаль международного научного симпозиума. Беларусь, Гродно, 6-10 мая 2005 г. (сс. 330-332). Гродно.
Ревенко, Е. М., Яцин, Ю. В., Кузьмин, В. А. (2005). Эффективность соревновательной деятельности боксеров, различающихся индивидуально-психологическими особенностями. Физическая культура и спорт в системе образования. Здоровьесберегающие технологии и формирование здоровья: материаль международного научного симпозиума. Беларусь, Гродно, 6-10 мая 2005 г. (сс. 341-344). Гродно.

\title{
JAUNŲJŲ BOKSININKŲ ATLETINIO IR SPECIALIOJO FIZINIO PARENGTUMO KAITA PIRMAIS SPORTINIO RENGIMO METAIS
}

\author{
Algirdas Čepulėnas, Vitalijus Subačius, Vidas Bružas, Pranas Mockus \\ Lietuvos kūno kultūros akademija, Kaunas, Lietuva
}

\section{SANTRAUKA}

Tyrimo tikslas - išanalizuoti pradedančiujų boksininkų atletinio ir specialiojo fizinio parengtumo kaita per metini pradinio rengimo ciklą.

Naudoti tyrimo metodai: literatūros šaltinių analizè, eksperimentas, testavimas, lyginamoji analizè, matematinè statistika.

Tiriamujų grupę sudare 14 boksininkų, kurie pirmus metus lankė bokso treniruotes. Boksininkų amžiaus vidurkis - 14,9 \pm 0,6 metų. Eksperimentas truko 10 mėnesiu (rugsèjo-birželio mènesiais). Per eksperimentą buvo taikyta vienos alternatyvos programa. Boksininkai treniravosi penkis kartus per savaitę po $1-1,5$ valandos. Pradinio rengimo programą sudarè: atletinis rengimas $-24,6 \%$, specialusis fizinis rengimas $27,6 \%$, techninis rengimas - $28,5 \%$, taktinis rengimas - $19,3 \%$ viso treniravimo pratyboms skirto laiko.

Boksininkai buvo testuojami tris kartus: I testavimas vyko spalio, II — vasario, III — birželio mènesi. Pradedančiujų boksininkų atletinio rengimo programą sudare šios treniruočių priemonès: fiziniai pratimai ant prietaisu, pratimai su partneriu, pratimai su svarmenimis, trumpujų nuotolių bėgimas, kroso bėgimas, šuoliai, kimštinio kamuolio metimas, žaidimai.

Naudotos šios specialiojo rengimo priemonès: imitavimo pratimai, pratimai su šokdyne ir lauko teniso kamuoliukais, pratimai prie bokso maišų, tiesūs ir šoniniai smūgiai ị bokso maišą, gynybos pratimai, smūgiu imitavimas su svarmenimis ir kimštiniais kamuoliais.

Per pradinio rengimo metinį ciklą boksininkų kūno sudèjimo rodikliai - ūgis, kūno svoris, Ketlè indeksas padidèjo $(\mathrm{p}<0,05)$, riebalų kiekis $(\%)$ kūne, kūno masės indeksas mažai keitèsi $(\mathrm{p}>0,05)$. Boksininkų dešinès plaštakos jẻga visų testavimų metu buvo didesnè negu kairès. Per vienerių metų pradinio rengimo ciklą pagerejo $(p<0,05)$ boksininkų atletinis ir specialusis fizinis parengtumas. Pagerèjo $(p<0,05)$ boksininku kompleksinio greitumo, staigiosios jègos, anaerobinès glikolitinès ištvermès, rankų jẻgos ištvermès ir lankstumo rodikliai.

Vienkartinių šoninių smūgių priekine ranka ị bokso maišą jèga $(\overline{\mathrm{x}} \pm \mathrm{SE})$ padidejo nuo $106,3 \pm 7,5$ iki $127,6 \pm 8,15 \mathrm{~kg}(\mathrm{p}<0,05)$. Vienkartinių tiesiujų smūgių pagrindine ranka jèga padidèjo nuo $135,2 \pm 7,43$ iki $158,5 \pm 6,74 \mathrm{~kg}(\mathrm{p}<0,05)$.

Boksininkų smūgiu skaičius per $8 \mathrm{~s}$ kiekvienu testavimo etapu didejjo $(\mathrm{p}<0,05)$ ir eksperimento pabaigoje boksininkai atlikdavo vidutiniškai 43,5 $\pm 2,9$ smūgio.

Vienos alternatyvos eksperimentu nustatyta sportinio rengimo programa pagerino jaunuju boksininku parengtumą ir nepakenkè jų sveikatai.

Treniravimo programos turinys ir treniravimo krūviai buvo veiksmingi: gerejjo atletinio ir specialiojo fizinio parengtumo rodikliai.

Raktažodžiai: atletinis rengimas, specialusis fizinis rengimas, bokso maišas, energijos sąnaudos, suminè energija, suminè jèga.

Gauta 2007 m. birželio 4 d.

Received on June 4, 2007

Priimta 2007 m. lapkričio 15 d.

Accepted on November 15, 2007
Algirdas Čepulènas

Lithuanian Academy of Physical Education (Lietuvos kūno kultūros akademija)

Sporto g. 6, LT-44221 Kaunas

Lithuania (Lietuva)

Tel +37037302645

E-mail a.cepulenas@1kka.1t 